CATHARSIS 9 (1) 2020

Halaman: 65-69

p-ISSN 2252-6900 I e-ISSN 2502-4531

UNNES

Catharsis: Journal of Arts Education

http://journal.unnes.ac.id/sju/index.php/chatarsis

\title{
Religious Messages in Rapa'i Tuha Aceh Song Lyrics
}

\author{
Kembang Ayu Agustya ${ }^{\bowtie}$, Udi Utomo, Triyanto Triyanto \\ Email: kembangayuagustya@yahoo.co.id
}

Universitas Negeri Semarang, Indonesia

Received 26 December 2019, Accepted 15 March 2020, Published 31 May 2020

\begin{abstract}
Rapa'i Tuha music comes from Aceh, there are many religious messages conveyed through song lyrics. The purpose of this study was to analyze the religious messages contained in the lyrics of the Rapa' $i$ Tuha Aceh music song. This research used a communication approach using qualitative research methods. Data collection techniques were using observation, interviews and documentation. Data analysis procedures were carried out through data reduction, presentation and verification. Data validity used triangulation of data sources, methods and theories. Analysis of religious messages in song lyrics in Rapa'i Tuha music used communication analysis by Effendy, namely the presence of messages and communicators, recipients of messages and the presence of media. The results of this study indicated that the Rapa'i Tuha contains religious messages namely the message of faith and the message of morals. Specifically, the findings in this study were that there was a message of faith which means everything that should be trusted, believed and faithful as a Muslim. As well as moral messages which are reflected in the behavior patterns of our fellow human beings where all of these religious messages are contained in song lyrics in Rapa'i Tuha Aceh music.
\end{abstract}

Keywords: Religious Messages, Song Lyrics, Rapa'i Tuha

DOI : https://doi.org/10.15294/catharsis.v8i4.37199 


\section{INTRODUCTION}

Indonesia is a rich country in artistic and cultural diversity, because it has a diverse nationality in it. Art and culture are two things that can not be separated because they are related to one another. Each work of art has a distinctive culture and has beautiful artistic value. Art comes from human culture which can be preserved and documented and published as an effort to elevate regional culture. Basically, the development of art can not be separated from social and cultural systems in a society. Culture also has a very large function for the community where traditional art is born, grows and develops in a society which is then passed down and passed down continuously from generation to the next (Jazuli, 1994).

Regional culture is reflected in the arts that are characteristic of the community. Based on its development, Acehnese culture is much influenced by Islamic civilization as seen from its culture and arts including traditional music and other Acehnese traditional arts. One of them is traditional Rapa'i music. Rapa'i traditional music in the life of the Acehnese people is used as a medium for da'wah in spreading Islam.

In this writing the researcher will examine the traditional music of Rapa'i Tuha Aceh. The traditional music of Rapa'i Tuha has been developed for a long time, which was originally as a medium in spreading Islam and is now changing as a medium of entertainment. Playing a traditional Rapa'i Tuha instrument requires cohesiveness, between one and the other which will then greatly affect the sound output (the sound) of the music being released. Through music, Rapai Tuha, the people of Aceh can complement each other so that good communication is created between the community (members of the player). Through the lyrics of the song Rapa 'i Tuha is used as a media for Da'wah to the people of Aceh and can also be used as a medium of entertainment. The traditional music of Rapa'i Tuha is also used as a medium for religious activities as well as entertainment that functions as a livelier and as a symbol of Islam to the people of Aceh, especially the people of Aceh Besar in the form of artistic activities. Therefore, the author is interested in studying this Rapa'i Tuha music.

The Rapa'i Tuha music play contains a number of song lyrics beginning with the saleum (opening), the story (both the story of the Prophet, the Prophet and religious teachings), and the closing. No exception, also the content of the moral message. In fact, then in terms of the form of music from the past until now it has never changed is still very traditional. The musicians of Rapa'i Tuha have different age levels ranging from teenage to adult levels. The traditional music of Rapa'i Tuha is played in groups with a semi-circular floor pattern. This research was conducted in a studio called the Rapa'i Tuha studio.

Based on the explanation above, it can be seen that the traditional music of Rapa'i Tuha is a traditional art that has been developing for a long time until now. Therefore, the writer is interested in researching Rapa'i Tuha music in terms of religious (religious) messages in the lyrics of Rapa'i Tuha songs. To maintain a traditional art, it needs to be developed through educational activities so that the district of Aceh Besar continues to maintain and preserve traditional culture in the area. According to Triyanto (2017: 80) education as a cultural process has two functions, namely as a means to preserve and a means to develop creativity. Although there is no specific specific research on music and song lyrics of Rapa'i Tuha, there are some relevant previous studies.

Some of the relevant previous studies are as follows first, Ransom (2015) wrote a research article entitled "Message in Music: Lyrics and Meaning", in the International Journal of Education and Art. The results of this study are music has long been an effective way to communicate with the masses and the lyrics in a song / music can play a big role in communicating. In this article also explains the song lyrics there are messages that can affect a person's behavior. 
Secondly, Evi Riyanti (2019) wrote a research article entitled "Analysis of Religious Values in Wali Band Lyrics on Cari Berkah Album ". The results of this study there is a religious value in the song Wali Band in which everyone who listens to the song's lyrics someone will be influenced to positive things and lead to goodness. Reminds humans of good behavior among humans and always maintaining good relations with the creator.

The results of previous studies, there are many studies that have not specifically examined the music and lyrics in the song Rapa'i Tuha. It is on this basis that research still needs to do a study of Rapa'i Tuha music then seg

\section{METHOD}

This research uses qualitative research methods with an interdisciplinary approach or uses more than one discipline. This research uses the discipline of communication. The communication approach is used to explain the message contained in the Rapa'i Tuha music song lyrics by using the Rapa'i Tuha Aceh music medium as the message conveyer. The target of the study in this research are religious messages on song lyrics in the music of Rapa 'i Tuha Aceh. Data collection techniques are done through observation, interviews and documentation.

Observation in this writing was done to obtain information by participating in the Rapa'i Tuha traditional music exercises. interviews were conducted with the studio leaders, studio members, trainers and the local community. through documentation obtained photographs, videos and documents relating to religious messages in song lyrics in the music of Rapa'i Tuha Aceh. The data validity technique in this study uses triangulation techniques. There are three forms of triagulation to maintain data credibility, namely (a) data trigulation, (2) source triagulation, and (3) method triagulation. At this writing to test the validity of the data used triagulation of sources, namely testing the data by checking the data that has been obtained through several sources. The data analysis technique of this study refers to the analysis of Miles and Hubermen, namely data reduction, data presentation, and data verification.

\section{RESULTS AND DISCUSSION}

Religious messages are religious messages that can invite someone to do good. According to Koentjaranigrat (1993: 144) religious messages are part of culture, each religion is a system consisting of four components, namely a belief system that contains all beliefs about the attributes of God, relations with humans and all values and norms. Ahmad (2005: 4) explains that religion is a form of human relations with its creators through religious teachings that have been internalized in a person and reflected in their daily attitudes and behavior. Religious messages are religious messages that can invite someone to do good. Both human relations with God, human relations, human relations with nature or the environment and relating to religious education.

Song lyrics is an expression of something that is heard or seen by someone experienced. The Rapa'i Tuha song comes out as a result of my servant's contemplation and love for his creator and explains about the relationship between man and his God, the relationship between humans and humans, and the relationship between humans and the social environment. In the lyrics song Rapa'i Tuha Aceh, there is a religious message that includes the message of faith and moral messages, both of which are elements of moral attitudes and values that must exist in human beings. Song lyrics can be said as one of the works of art is written and its form is almost similar to the form of lyrics (Awi, 2003: 50). Analysis of the song lyrics of Rapa 'i Tuha which contains religious messages includes the message of faith and character as outlined in the song lyrics as follows:

Astagfirullah halazim Mingkulli zambil Azim 
Awwallawal ak'hirah

Walakhira walbatina

Ya..Ghafurrurrahim

Astagfirullah halazim

Mingkulli zambil Azim

Minfazami waba shabir

Allah, ya Ghafururrahim

Astagfirullah hal'ana

Wali-wali dina

Wali masya'iftima

Wali Jami'il Muslimin

Wali Jami'il Aulia

Wasyuhada'i wasahbini

Shallahuala Muhammad

Shallahuala Alaihi Wassalam

Ya..Allah Ate'uh Nabi Muhammad

Yang kamo rahmat dan salam.

Analysis of religious messages in song

lyrics in Rapa'i Tuha music uses communication analysis according to Effendy, namely the presence of messages and communicators, recipients of messages and the presence of media. The results of this study indicate that Rapa'i Tuha as a medium of communication, sheh (artists) act as communicators and the community as communicants (recipients of messages). In this study the messages conveyed contained religious messages namely the message of faith and moral messages. The message of faith in the song lyrics is everything that should be believed, believed and believed as a Muslim. The message of morals is reflected in the behavior patterns of our fellow humans. The religious message of the song lyrics in Rapa'i Tuha music is the message of faith and character. Aqeedah is an inner belief, that is, a Muslim's belief in the existence of Allah SWT and all its powers.

Astaghfirullah (أستغفراله') is the act of apologizing or asking Allah for forgiveness by Muslims. This is an action recommended in Islamic teachings. then Shallahuala Muhammad taught and invited us to pray for the Prophet. We are encouraged to recite shalawa every time he mentions the name of the Prophet sallallaahu sallallaahu or hears his name mentioned. Then the analysis of religious messages contained in the song lyrics Rapa' $i$ Tuha also includes moral messages namely human attitudes and actions.
According to Asraman (1994:7) explains the attitude of morality includes mutual respect and respect for fellow Muslims. Just as the moral message contained in the song Rapa' $i$ Tuha Aceh explains the relationship between humans and humans and the relationship between humans and their environment. From the discussion above it can be said that the Rapa'i Tuha lyrics contains religious messages and there is communication between the Rapa' $i$ Tuha music player and the people who listen to it. And hope that the song of the Rapa'i Tuha song can be applied by the community in everyday life.

\section{CONCLUSION}

Based on the discussion above, it can be concluded as follows: (1) Rapa'i Tuha lyrics containing religious messages include moral and religious messages; (2) In the lyrics of the song Rapa'i Tuha contains an invitation to remember Allah and Rasullullah and the behavior or morals of both fellow human beings and their environment; (3) Through the Rapa'i Tuha Aceh lyrics there is a means of communication media to deliver religious messages to the listening community.

\section{SUGGESTION}

This research is the first study that the authors did, namely analyzing religious messages in the song poetry Ruhai Tuha Aceh. The author realizes that there are still many shortcomings in this study. Therefore, researchers hope to continue research on religious messages in the poetry song Ruhai Tuha Aceh, because this study is very interesting to be studied further. This is because the song Rapa 'i Tuha not only contains religious messages but can also be used as a means of entertainment (art) as well as a medium for propagation in spreading the religion of Islam. 


\section{REFERENCES}

Asraman. 1994. Pengantar Studi Akhlak. Jakarta: PT Raja Grafindo Persada.

Arif, A F. 2017. "BentukMusik dan Nilai dalam Perspektif Aksiologi pada Kesenian Terbangan di Kabupaten Lahat Sumatra Selatan". Tesis. Universitas Negeri Semarang.

Indrawan, Bagus dkk. 2016. "Bentuk Komposisi dan Pesan Moral dalam Pertunjukan Musik Kiaikanjeng". Chatharsis: Journal of Arts Education. Vol 2. (3)

Jazuli, M. 1994. Telaah Teoritis seni Tradisional. Semarang: IKIP Semarang Press.

Jazuli, M. 2008. Paradikma Kontekstual Pendidikan Seni. Semarang: Unnes University Press.

Merriam. Alan P. 1964. The Antropology Of Musik. Northwesterm: University Press.
Netriroza, Arifni. 2007. Masyarakat dan Kesenian Aceh. Etnomusikologi: Jurnal Pengetahuan dan Seni. 2(6):196

Patricia, Ransom F. 2015. "Message in The Music: Do Lyrics and its Meaning". Journal Internasional Education and Art.

Raharjo, Tri Joko. 2005." Peran Seni Proses Pembelajaran Pendidikan Luar Sekolah". Harmonia Pengetahuan dan Pemikiran Seni. Mei, Vol.4 No.2

Riyanti, Evi. 2019." Analisis Nilai-Nilai Religius dalam Syair Lagu Wali Band Pada Album Cari Berkah". Jurnal Universitas Muhammadiyah Malang.

Siti Risa Noviyanti, Sutiyono. 2017." Bentuk, Perubahan Fungsi dan Nilai- Nilai Edukatif Pada Musik Tari JapinTahtul di Amuntai. Vol. 15, No. 1, April 2017: 97 - 112. JurnalImagi.

Supanggah, R. 1995. Etnomusikologi. Yogjakarta: Yayasan Bentang Budaya. 